\title{
The effects of biocrusts on soil parameters in a semi-arid pediment at north-eastern Iran
}

\author{
Atoosa GHOLAMHOSSEINIAN ${ }^{1}$, Adel SEPEHR ${ }^{1 *}$, Iraj EMADODIN ${ }^{2}$ \\ ${ }^{1}$ Department of Desert and Arid Zones Management, Ferdowsi University of Mashhad, Azadi Square, \\ Mashhad, Iran \\ 2Institute for Crop Science and Plant Breeding, Christian Albrechts University of Kiel, Hermann \\ Rodewald Str. 9, 24118, Kiel, Germany
}

Received 13 July 2020; Revised 17 October 2020; Accepted 20 October 2020

*Correspondence to: Adel SEPEHR, e-mail: adelsepehr@um.ac.ir

\begin{abstract}
In arid and semi-arid environments, soils are very fragile. Their degradation rapidly reduces the biological potential and disrupts the ecological and socio-economic balance. Living within a few millimetres of the soil surface, biocrusts are organised into communities of biota and play an important role in soil stability and preservation. They are mainly composed of cyanobacteria, lichens, mosses, fungi, eukaryotic algae and other heterotrophic bacteria. Soil-biocrusts interaction is therefore very important and a good knowledge of this interaction allows a better management of soils, especially in arid and semi-arid environments. Thus, the link between cyanobacteria species and physicochemical parameters and soil mineralogy was studied in two geomorphological zones of northeast of Iran. Cyanobacteria are the main photosynthetic component of biocrusts. Samples were collected in summer along a linear transect by using $50 \times 50 \mathrm{~cm}$ quadrates for each study zone. Individual mineral soil particles were analysed by scanning electron microscopy (SEM). The amounts of $\mathrm{Na}, \mathrm{K}, \mathrm{Ca}$ and $\mathrm{Mg}$ as well as electrical conductivity and soil organic carbon are higher in the presence of biocrusts (Takhte Soltan site) than in their absence (Sabzevar Playa site). Biocrusts increased levels of organic carbon, $\mathrm{pH}$, calcium carbonate, exchangeable sodium and potassium percentages. Results indicated that soil properties regarding soil organic carbon, $\mathrm{CaCO}_{3}$ and amount of clay changed among biocrust sand bare soils. This research considers further attention to biocrusts because of their multiple ecosystem roles and their importance in the constitution of dryland ecosystems.
\end{abstract}

KEYWORDS arid and semi-arid; biocrusts; cyanobacteria; soil physicochemical properties; mineral erosion; Iran

\section{Introduction}

Biological soil crusts (BSCs) are the dominant biological surface features in many arid and semiarid area supporting vascular plant communities (Maier et al., 2016) and are sensitive indicators of desertification (Belnap et al., 2001; Coe et al., 2012; Read et 
al., 2014; Delgado-Baquerizo et al., 2016). During dry periods and droughts, biocrusts often provide the only biological form of soil cover (Eldridge and Greene, 1994). Biocrusts such as lichens, mosses, fungi, cyanobacteria, eukaryotic algae, and other heterotrophic bacteria, live within or on the very top of soil surface (Belnap et al., 2003a; Rozenstein et al., 2014). They find almost all over the world, in all climatic regions, mesic environments tropical and temperate deserts and in the polar regions of the globe (West, 1990; Eldridge and Greene, 1994; Prasse and Bornkamm, 2000; Karnieli et al., 2002; Qin and Ferrara, 2007; Buis et al., 2009). Biocrusts play several important roles in arid and semi-arid ecosystems, including atmospheric nitrogen-fixation, increasing soil fertility, promoting water infiltration, seedling germination, increasing soil stability, improving soil properties and reducing soil erosion by wind (Greene and Darnall, 1990; Eldridge and Greene, 1994; Evans and Johansen, 1999; Eldridge et al., 2000; Belnap, 2003b; Belnap 2006; Miller et al., 2011; Liu et al., 2013 and Xu et al., 2013). Some field and laboratory studies indicated that biocrusts enhance the content of soil elements such as $\mathrm{Ca}, \mathrm{Mg}, \mathrm{K}, \mathrm{Fe}, \mathrm{N}, \mathrm{P}$ and $\mathrm{S}$ (e.g. Belnap and Harper, 1995), and soil temperature (Belnap et al., 2001). Evidences show that biocrusts play also an important role in soil formation, preventing water and wind erosion and increasing soil fertility by $\mathrm{N}$ and $\mathrm{C}$ fixation, (Evans and Ehleringer, 1993; Lange et al., 1994). They provide suitable conditions for the establishment of vascular plants (Eldridge and Greene, 1994; Belnap and Lange, 2013; Belnap, 2003c). According to Belnap et al. (2001) up to $70 \%$ of the $N$ fixed by cyanobactria and cyanolichens is released into the surrounding soil environment and is available for vascular plants. Despite several studies have been done in the field of biocrusts globally (Belnap 2006; Chamizo et al., 2012a; Bowker et al., 2013; Chen and Duan, 2015), there are relatively few studies on the influences of biocrusts on soil physical and chemical characteristics. In this research, we studied soil characteristics under biocrusts as well as the interaction between biocrusts and soil in two geomorphologic sites with aridisols and solonchak soils. It is hypothesized that biocrusts have positive effects on soil chemical and physical characteristics in the study area.

\section{Data and Methods}

\subsection{Study sites}

Around $75 \%$ of Iran is covered by drylands and regarding the land overuse and unsustainable land management, soil erosion is very intense in this area. Two sites in the semi-arid region of KhorasanRazavi (north-eastern Iran) were selected (Fig. 1). Takhte Soltan (TS), with a size of $1854 \mathrm{~km}^{2}$ is located at 36 $16^{\circ} 00^{\prime \prime}-36^{\circ} 15^{\prime} 00^{\prime \prime} \mathrm{N}, 60^{\circ} 59^{\prime} 00^{\prime \prime}-61^{\circ} 58^{\prime} 20^{\prime \prime} \mathrm{E}$. The topographical elevation of the study area varies between $750 \mathrm{~m}$ and $900 \mathrm{~m}$ a.s.l. It is a hilly area with a semi-arid (steppe) climate according to the Köppen climate classification. The average annual precipitation is $202 \mathrm{~mm}$. January and February are the coldest months of the year with a mean air temperature of about $1^{\circ} \mathrm{C}$. The highest average air temperature is $28.4^{\circ} \mathrm{C}$ in July. The dominant wind patterns include 120 days which usually blow from north and north-east, causing dust storms. The particle size distribution in the soil shows sandy loam textures. Rocks are mostly sandstone, conglomerate and shale (Table 1).

Sabzevar Playa (SP), with a size of about 2648 $\mathrm{km}^{2}$ is located at $35^{\circ} 55^{\prime} 00^{\prime \prime}-36^{\circ} 25^{\prime} 00^{\prime \prime} \mathrm{N}, 56^{\circ} 15^{\prime}$ $00^{\prime \prime}-57^{\circ} 45^{\prime} 00^{\prime \prime} \mathrm{E}$, in the eastern great Kavir basin. The topographical elevation of the study area varies between $750 \mathrm{~m}$ and $900 \mathrm{~m}$ a.s.l., The average topographical elevation of the region is over $750 \mathrm{~m}$ a.s.l. The general physiographic trend of the playa extends east to west along the Kal-Shour stream with an average length of $120 \mathrm{~km}$. In addition to windborne sand dunes, volcanic rocks, tuffs and pelagic carbonate rocks formed in the upper Cretaceous period and earlier can be found around the playa. The study area has a semi-arid climate with annual precipitation of 150-200 $\mathrm{mm}$ and average annual temperature of $16-17^{\circ} \mathrm{C}$. According to particle size classifications, soils of the investigation areas are generally sandy-loam in TS (Takhte Soltan) and silty in SP (Sabzevar Playa) (Table 1). 


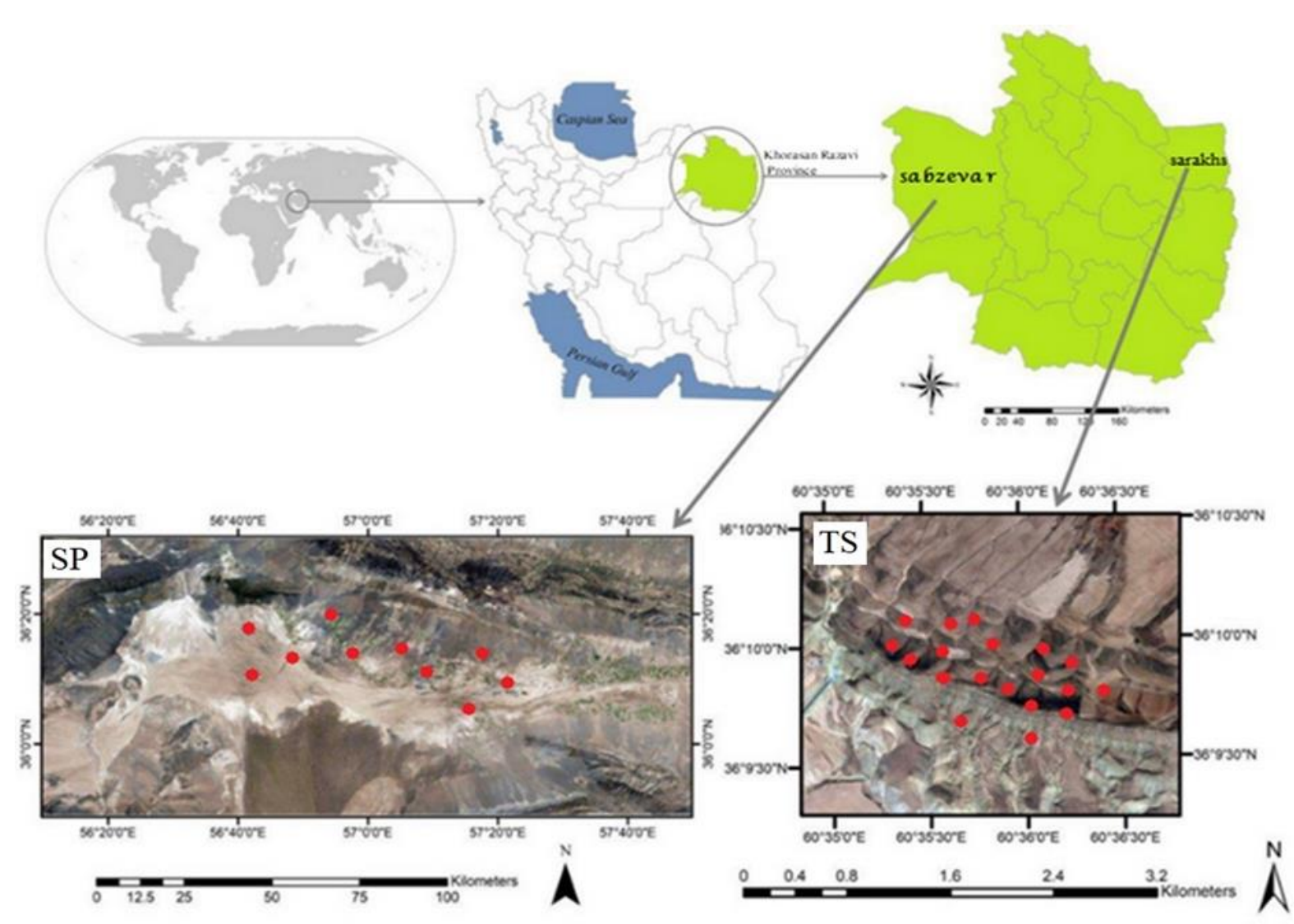

Figure 1 Location of the study area in Khorasan Razavi province, Iran (sampling points are marked with red circles). TS (Takhte Soltan), SP (Sabzevar Playa).

Table 1 Specifications of the study area.

\begin{tabular}{lll}
\hline & SP & TS \\
\hline Climate (Koppen) & BSK & BSK \\
Rainfall average $(\mathrm{mm})$ & $150-200$ & $200-250$ \\
Average annual temperature $\left.{ }^{\circ} \mathrm{C}\right)$ & $16-17$ & $14-15$ \\
Topographical elevation $_{\text {Soil classification }}$ & $650 \mathrm{~m}$ & $750 \mathrm{~m}$ \\
Soil texture & Solonchak & Aridisols-Vertisols \\
Deposition & silt & sandy loam \\
Geomorphology & Cretaceous & Quaternary-Cenozoic \\
Rock & Playa & Pediment and Alluvial fans \\
& sand dunes, volcanic rocks, tuffs, & sandstone, conglomerate, shale, \\
\hline
\end{tabular}

\subsection{Sampling}

Samples were collected in September 2017 along a linear transect with a length of $50 \mathrm{~m}$ using $50 \times 50$ $\mathrm{cm}$ quadrates. All soil samples were taken in $10 \mathrm{rep}-$ licates from the topsoil (upper $5 \mathrm{~cm}$ ) as the purpose focused on Epilithic species living on topsoil and rocks. Distance between each quadrat was 5 meters along the experimental transect according to its entire length. To compare the effects of biocrusts on the soil properties and vice versa, samples were collected in two zones including biocrusts and nonbiocrusts. Twenty samples were taken from areas with biocrusts in the Takhte-Soltan region and areas 
with non-BSC in the Sabzevar Playa region, respectively (Fig. 2). Samples were stockpiled in plastic bags and transferred to the laboratory of Natural Resources and Environment Faculty. The samples were kept at about $4^{\circ} \mathrm{C}$ in an isolated room.

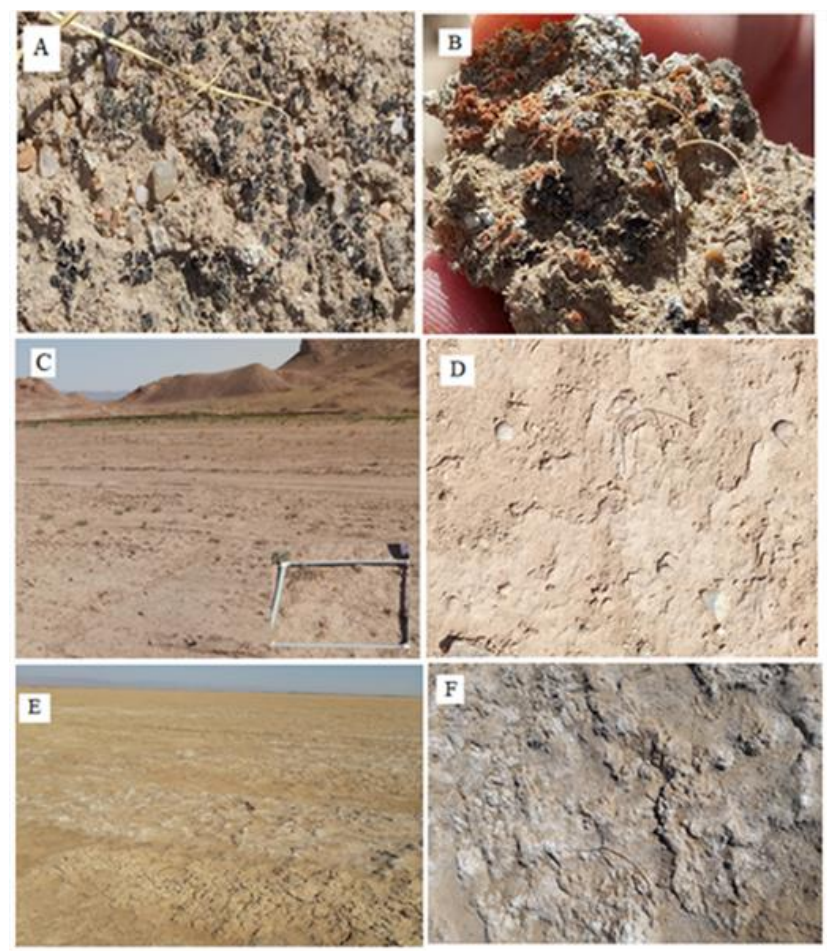

Figure 2 A and B biocrusts in TS (Takhte Soltan); C. landscape of the TS area; D. bare soil (without biocrusts) in TS; E. and F. bare soil in SP area; F. accumulation of minerals and salts on soil surface.

\subsection{Laboratory analysis}

The soil and biocrusts samples were air-dried and sieved to $2 \mathrm{~mm}$. Sub-samples were mixed in a mechanical agate mortar to obtain the $0.5 \mathrm{~mm}$ particle size necessary for the determination of organic carbon and exchangeable cations. Soil samples were analysed for physicochemical characteristics as follows: $\mathrm{pH}$ was determined with a soil-water suspension with a ratio of $1: 2.5$ by a $\mathrm{pH}$ meter (Rayment and Lyons, 2011); soil electrical conductivity (EC) was measured by a soil-water suspension in with a ratio of 1: 5 by an EC meter (Rayment and Lyons, 2011). Soil organic carbon (SOC) was estimated by the Walkley and Black method modified by Mingorance et al. (2007). Calcium carbonate (Nelson and Sommers, 1982), exchangeable cations ( $\mathrm{Ca}, \mathrm{Mg}, \mathrm{Na}, \mathrm{K}$ ) and cation exchange capacity (CEC) were measured by the formation of $\mathrm{Cu}$ (II) complexes with triethylenetetramine followed by photometric analyses (Meier and Kahr, 1999); soil moisture was calculated by the gravimetric (weighing) method.

In order to determine the cyanobacteria and green algae crusts, the soil surfaces were studied by stereomicroscope (Nicon SMZ-1) and optical microscope (Echo um-210 BD). Also, for better diagnosis and identification of species, samples were cultivated using the cultivation method applied by Kaushik (1987).

The study of moss and lichens was carried out through a morphological study by stereomicroscope (Nicon SMZ-1). Moreover, for the better evaluation of the lichens, the determination of the algae type and the details of the ascocarp-shaped structure have been done by sharp blade cutting and optical microscope observation (Echo um-210 BD). After cultivating, we identified species based on related researches including (Fang et al., 2007; Bilgrami and Saha, 2004; Komárek, 2005; Luton et al., 1999; Johnson et al., 2005; Hassler et al., 2012; Vijayan and Ray, 2015; Kumar et al., 2016; Moniri and Sipman, 2009; Zedda et al., 2000; McCune, 2007).

For scanning electron microscopy SEM, small part of the undisturbed samples was glued onto Aluminium stubs with the exposed vertical natural section facing upward and coated gold or platinum (Cox et al., 1989). Observations of the microstructures of soil crust were performed on a Leo 1450VP Scanning Electron Microscope (SEM, LEO, and Germany).

\subsection{Statistical analysis}

The effects of biocrusts on soil physicochemical properties on soil and differences between biocrusts, non-biocrusts and bare soils were analyzed in SPSS (Version 20.0) with t-test $(P<0.05)$ used to test. At first, the parameters were normalized by the Kolmogorov-Smirnov test. Then, by using the t-test, in the $5 \%$ statistical significance, the groups were evaluated. To investigate the effect of biocrusts on physicochemical parameters of the soil were compared in each catchment (non-biocrusts layer was compared with biocrusts surfaces). 


\section{Results}

\subsection{Biocrust influences on soil physicochemical properties}

The current study indicated that biocrusts have significant effects on most physical and chemical characteristics (Table 2). $\mathrm{Na}, \mathrm{K}, \mathrm{Ca}$, and $\mathrm{Mg}$ content, EC and SOC have changed significantly between different sites.

Sand, silt and clay contents varied significantly under the crust types in TS (Table 2). No significant difference in soil texture was found between the biocrusts and non-biocrusts layers. A significant difference in sand and silt contents was observed between soils with a crust (biocrusts and non-biocrusts) and bare soils. Although clay content of bare soil was higher, the difference was statistically significant. Comparison of sand, silt, and clay contents between the biocrusts site and the non-biocrusts site show significant differences for all three-particle size classes.

Soil texture by affecting on soil moisture, play an important role in composition and distribution of biocrusts (Kidron, 2016), the dominant texture is sandy-loam in TS and silty in SP. The amount of sand under biocrusts was significantly higher than in bare soils, and in a non-biocrusts site, the percentage of clay was significantly higher. Soil moisture content was higher in soils without biocrusts in surface layer, but was not statistically significant. In the TS site, the biocrusts samples and the non-biocrusts samples did not differ significantly regarding moisture. In soil with biocrusts the electrical conductivity $(\mathrm{ds} / \mathrm{m})$ was significantly lower than bare soils.

Regarding soil $\mathrm{pH}$, there were significant differences $(\mathrm{p}<0.05)$ between $\mathrm{pH}$ under biocrusts and bare soil (Table 2). Moreover, soil pH under biocrusts and non-biocrusts site was not statistically significant. Organic carbon in biocrusts soils was lower than bare soils, according to Table 2. The total content of soil organic carbon in the upper $5 \mathrm{~cm}$ of the soils under non-biocrusts was significantly lower than the organic carbon content under biocrusts. The amount of calcium carbonate in the TS region (biocrusts area) was higher than SP (bare soil), but this difference was not statistically significant. For $\mathrm{Na}, \mathrm{Ca}, \mathrm{Mg}$ and $\mathrm{K}$ exchange, there is a significant difference between the two sites, the number of ex- changeable cations for the bare soil area was significantly higher. Exchangeable cations content shows no variation between soil under biocrusts and non-biocrusts.

The cation exchange capacity, SAR and ESP of soils are more dependent on the type of soil and soil organic carbon content. As a result, due to the high levels of above two factors, the CEC, SAR, and ESP are also significantly higher in the bare soil site. Exchangeable cation content, CEC, SAR, and ESP show no significant differences between soil under biocrusts and non-biocrusts.

Micrograph of the samples in ppl (plane-polarized light) and scanning electron microscopy (SEM) observations of biocrusts in TS showed aggregations of fungal hyphae (Fig. 4). Connecting of individual grains was observed by the hyphae of lichens and fungi, polysaccharide of cyanobacteria (Fig. 4).

\subsection{The dominant species of Biocrusts in the TS region}

Biocrusts site presented higher cyanobacteria, green algae and lichens biodiversity and species richness than non-biocrusts site (Figs. 7 and 8; Table 4). The dominant species of cyanobacteria include: Oscillatoria limosa, Oscillatoria irrigua, Phormidium favosum, Phormidium ambiguum, Phormidium uncinatum, Pseudanabaena $s p$, and Microcoleus vaginatus.

Some of these species such as Leptolyngbya boryana, Microcoleus vaginatus, Nostoc commune, Oscillatoria curviceps and Oscillatoria tenuis were also found in the non-biocrusts soil. The dominant species of green algae including: Neochloris $s p$, Chlorococcum sp, Chlorella sp, Planktosphaeria, Rhizoclonium, Oedogonium, Microspora, Euglena and Protococcus observed on both sites with biocrusts and non-biocrusts. Two species Chlorococcum $s p$ and Chlorella $s p$ were also observed in the soil under abandoned agricultural land. The dominant lichens also in the study area are: Collema tenax, Psora decipiens, Toninia candida, Caloplaca microthallina, Circinaria mansourii, Leptogium, Candelariella vitelline, Gyalolechia subbracteata, Rinodina bischoffii, Endocarpon unifoliatum, Endocarpon pusillum and Sarcogyne. 
GHOLAMHOSSENIAN et al. / Revista de Geomorfologie 22 (2020)

Table 2 Statistical assessment of mean and variance differences between two sites TS (biocrusts) and SP (bare soils).

\begin{tabular}{|c|c|c|c|c|c|c|c|}
\hline \multirow{2}{*}{ Elements } & \multicolumn{2}{|c|}{$\begin{array}{c}\text { Levene's Test for Equality of } \\
\text { Variances }\end{array}$} & \multicolumn{3}{|c|}{ t-test for Equality of Means } & \multirow{2}{*}{$\begin{array}{l}\text { Mean Differ- } \\
\text { ence }\end{array}$} & \multirow{2}{*}{$\begin{array}{l}\text { Std. Error Dif- } \\
\text { ference }\end{array}$} \\
\hline & $\mathrm{F}$ & Sig. & $t$ & $d f$ & Sig. (2-tailed) & & \\
\hline $\mathrm{EC} \mathrm{ds/m^{* }}$ & 26.652 & 0.000 & -17.295 & 9.000 & 0.000 & -1.923 & 0.111 \\
\hline pH & 1.355 & 0.260 & 0.158 & 18.000 & 0.876 & 0.008 & 0.054 \\
\hline SOC \%* & 0.592 & 0.452 & -3.513 & 18.000 & 0.002 & -0.567 & 0.161 \\
\hline $\mathrm{CaCO}_{3}$ & 7.365 & 0.014 & 1.704 & 13.342 & 0.112 & 5.2041 & 3.05 \\
\hline $\mathrm{Na}(\mathrm{mg} / \mathbf{k g})^{*}$ & 0.192 & 0.667 & -5.367 & 18.000 & 0.000 & -1.601 & 0.298 \\
\hline$K(\mathrm{mg} / \mathrm{kg})^{*}$ & 0.014 & 0.908 & -7.299 & 18.000 & 0.000 & -28.254 & 3.871 \\
\hline $\mathrm{Ca}(\mathrm{mg} / \mathrm{kg})^{*}$ & 3.890 & 0.064 & -9.314 & 18.000 & 0.000 & -1.943 & 0.209 \\
\hline$M g(\mathbf{m g} / \mathbf{k g})^{*}$ & 0.276 & 0.606 & -2.449 & 18.000 & 0.025 & -0.951 & 0.388 \\
\hline SAR* $^{*}$ & 8.353 & 0.010 & -12.041 & 9.085 & 0.000 & -1.911 & 0.159 \\
\hline ESP* & 14.922 & 0.001 & -12.399 & 9.083 & 0.000 & -1.812 & 0.146 \\
\hline CEC* & 1.899 & 0.185 & -3.113 & 18.000 & 0.006 & -1.051 & 0.338 \\
\hline Moisture\% & 0.013 & 0.911 & -0.739 & 18.000 & 0.469 & -0.073 & 0.098 \\
\hline sand* & 0.414 & 0.528 & 3.573 & 18.000 & 0.002 & 35.235 & 9.862 \\
\hline silt* & 0.005 & 0.942 & -3.915 & 18.000 & 0.001 & -37.657 & 9.619 \\
\hline clay* & 4.363 & 0.051 & 0.609 & 18.000 & 0.550 & 1.647 & 2.706 \\
\hline
\end{tabular}

*represent significant at $95 \%$ confidence interval or $\mathrm{P}<0.05$

Table 3 Statistical assessment of mean and variance differences between two sites biocrusts and non-biocrusts in TS area.

\begin{tabular}{|c|c|c|c|c|c|c|c|}
\hline \multirow{2}{*}{ Elements } & \multicolumn{2}{|c|}{$\begin{array}{c}\text { Levene's Test for Equality of } \\
\text { Variances }\end{array}$} & \multicolumn{3}{|c|}{ t-test for Equality of Means } & \multirow{2}{*}{$\begin{array}{l}\text { Mean Differ- } \\
\text { ence }\end{array}$} & \multirow{2}{*}{$\begin{array}{l}\text { Std. Error Differ- } \\
\text { ence }\end{array}$} \\
\hline & $\mathrm{F}$ & Sig. & $\mathrm{t}$ & df & Sig. (2-tailed) & & \\
\hline $\mathrm{EC} \mathrm{ds/m}$ & 10.460 & 0.005 & -1.539 & 11.477 & 0.151 & -0.488 & 0.317 \\
\hline pH & 4.276 & 0.053 & -1.974 & 18.000 & 0.064 & -0.207 & 0.105 \\
\hline SOC \%* & 2.156 & 0.159 & 5.888 & 18.000 & 0.000 & 1.025 & 0.174 \\
\hline $\mathrm{CaCO}_{3}$ & 1.194 & 0.289 & 2.847 & 18.000 & 0.011 & 13.577 & 4.769 \\
\hline $\mathrm{Na}(\mathrm{mg} / \mathrm{kg})$ & 0.014 & 0.908 & 0.299 & 18.000 & 0.768 & 0.082 & 0.274 \\
\hline$K(\mathbf{m g} / \mathbf{k g})$ & 0.285 & 0.600 & 0.501 & 18.000 & 0.622 & 2.080 & 4.149 \\
\hline $\mathrm{Ca}(\mathbf{m g} / \mathbf{k g})$ & 0.283 & 0.601 & -1.187 & 18.000 & 0.251 & -0.326 & 0.275 \\
\hline$M g(\mathbf{m g} / \mathbf{k g})$ & 0.006 & 0.941 & 1.145 & 18.000 & 0.267 & 0.396 & 0.346 \\
\hline SAR & 0.203 & 0.658 & -0.339 & 18.000 & 0.739 & -0.085 & 0.251 \\
\hline ESP & 0.569 & 0.460 & 0.202 & 18.000 & 0.842 & 0.054 & 0.267 \\
\hline CEC & 0.127 & 0.725 & -1.194 & 18.000 & 0.248 & -0.600 & 0.502 \\
\hline Moisture\% & 5.278 & 0.034 & -1.136 & 12.434 & 0.277 & -0.194 & 0.171 \\
\hline sand* & 1.944 & 0.180 & -2.792 & 18.000 & 0.012 & -21.773 & 7.798 \\
\hline silt $^{*}$ & 6.408 & 0.021 & 3.728 & 11.909 & 0.003 & 27.704 & 7.431 \\
\hline clay* & 0.156 & 0.697 & -2.127 & 18.000 & 0.047 & -6.704 & 3.152 \\
\hline
\end{tabular}

*represent significant at $95 \%$ confidence interval or $\mathrm{P}<0.05$ 

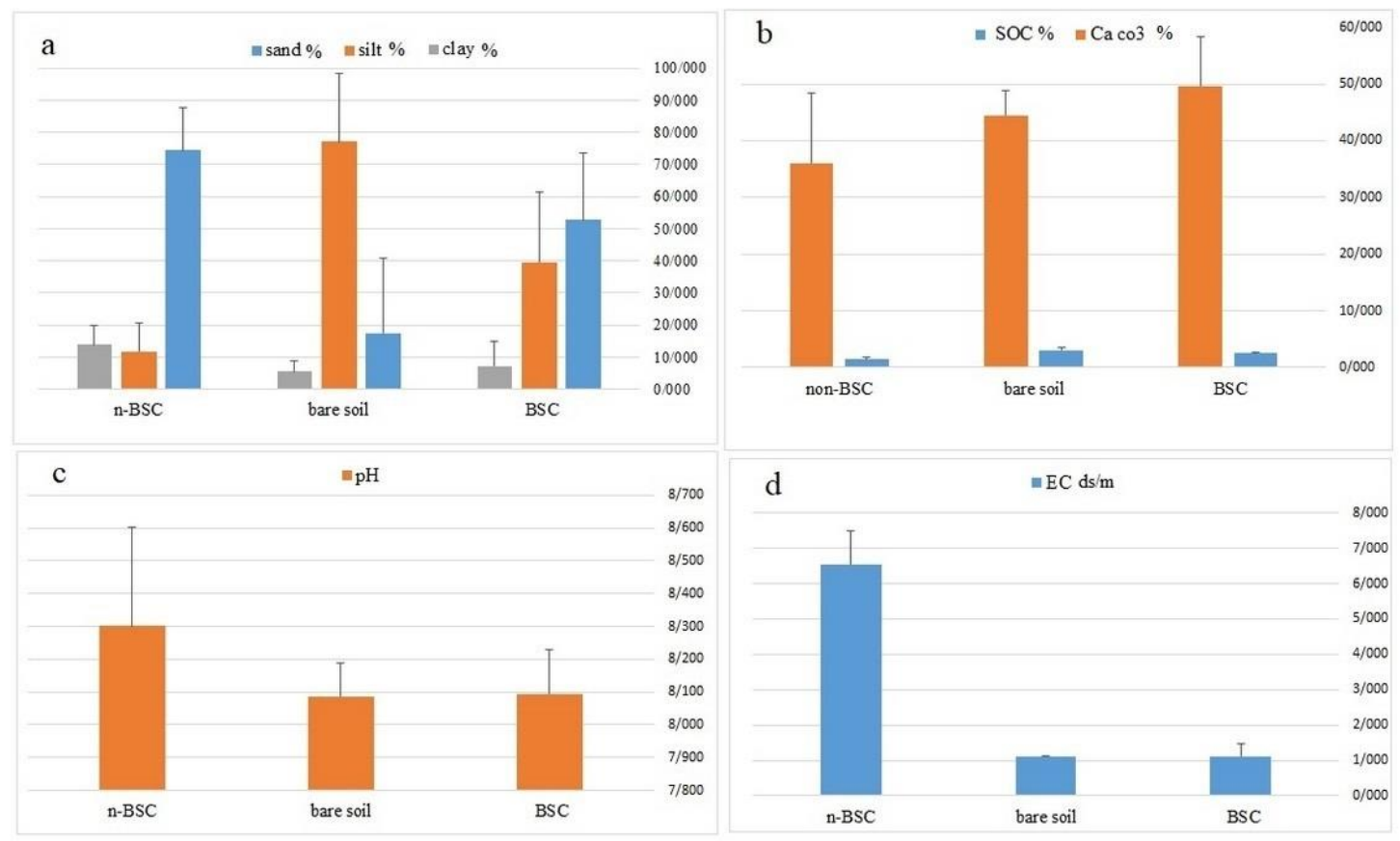

Figure 3 Mean $( \pm S D, n=30)$ sand, silt and clay in the three soil layers (a) Calcium carbonate (CaCO3) and Soil organic carbon content (SOC) (b) $\mathrm{pH}(\mathrm{c})$ and $\mathrm{EC} \mathrm{ds} / \mathrm{m}(\mathrm{d})$. (BSC and $\mathrm{n}-\mathrm{BSC}$ ) from TS region.
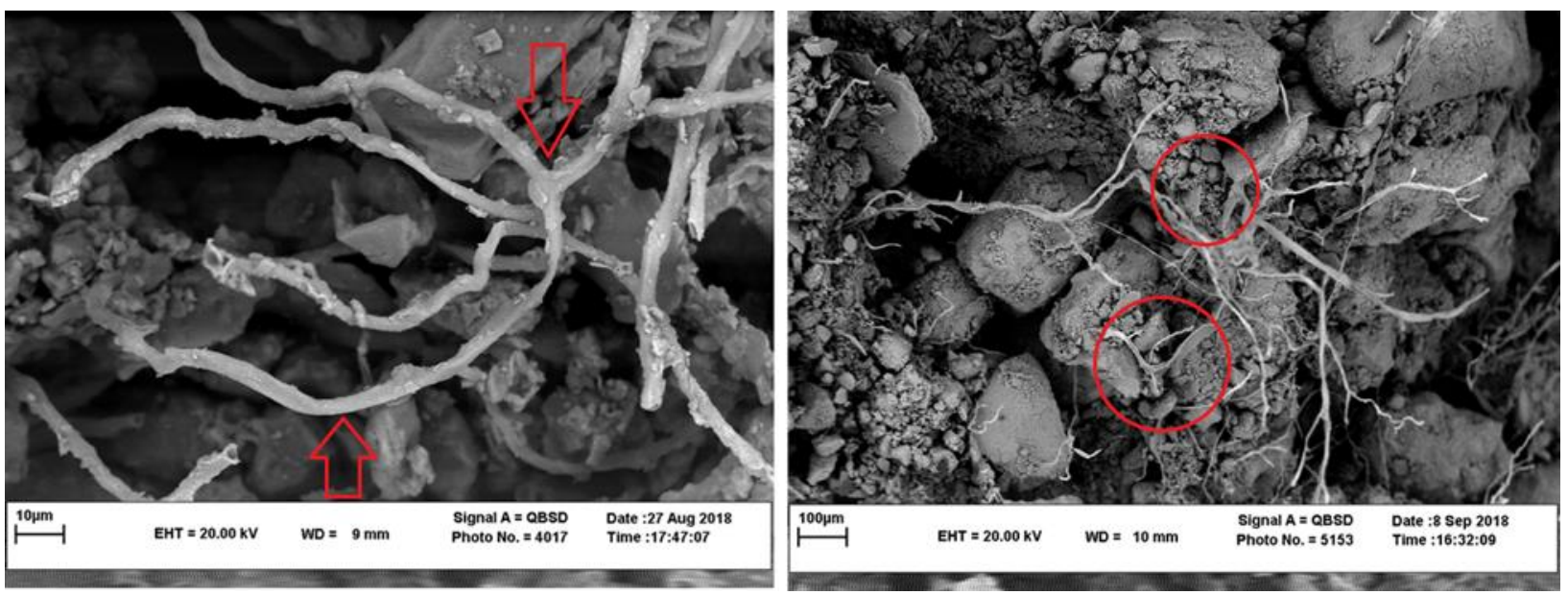

Figure 4 The polysaccharide attached Clay particles. The polysaccharide filaments that enclose the clay particles are marked in the figure with arrows and a red circle.

\section{Discussion}

Biocrusts affect nutrient cycling as well as hydrological processes in early soil succession processes. Several studies show that biocrusts could affect the weathering of racks and thus contribute to the formation of soil and distribution of the particle size (Souza-Egipsy et al., 2004; Aghamiri and Schwartzman, 2002). Moreover, many studies have indicated an increase in soil moisture (Issa et al., 2007), N and
SOC content in the soils with biocrusts (Rogers and Burns, 1994; Gao et al., 2010).

\subsection{The effect of biocrusts on physicochemical properties}

In our study, some physicochemical properties such as EC, pH, SOC, exchangeable cations, SAR, ESP, CEC and moisture were lower in biocrusts compared to bare soils. 
Soil $\mathrm{pH}$ under the biocrusts areas was lower than bare and non-biological crust soils, although there is not significant different between sites. Increase in microbial population, and carbon dioxide generation as well as higher respiration found in biocrusts could decrease pH (Büdel, 2005; Lane et al., 2013). Chamizo et al. (2012b) and Miralles et al. (2012) found that the soil pH decreased with the development of biocrusts from primary sequences such as cyanobacteria to the final sequence, such as mosses and lichens. Mirales et al. (2013) found that compared to the soil without crusts with cyanobacterium and lichen substrates, $\mathrm{pH}$ for coverless soil <cyanobacteria> lichen, which indicates a decrease in soil $\mathrm{pH}$ in the presence and development of biocrusts. There is an interaction between soil $\mathrm{pH}$ and soil organic carbon. Biocrusts have a significant role in producing organic carbon through the carbon fixation (Beymer and Cleopathek, 1991; Danin and Ganor, 1991). Phillips and Belnap (1998) indicated that carbon stabilization increases in the presence of licorice and moss. Increasing in the infiltration and reduction of cations at the surface and consequently the decrease of $\mathrm{pH}$ at the soil level is accurate for comparison between two bare and crustal zones, but the amount of cations in two sites with crust and without crust is not significant and the lower $\mathrm{pH}$ content in the soil to the crusty surface can be associated with increased microbial respiration (Chamizo et al., 2012a).

In this study, bare soils (playa) had much higher values of sodic and saline properties such as $\mathrm{Ca}, \mathrm{Na}$, Mg, EC, ESP and SAR. Similarly, Abed et al. (2013) showed that biocrusts soils had less $\mathrm{pH}$ and EC than bare soils. Subsequent evaporation and ponding of water in these areas would leave substantial amounts of salts behind (Kakeh et al., 2018). High evaporation causes salinity that could build up to the surface (Fig. 2F). Increasing salinity has reduced colonization of plants or biocrusts, thus also increasing the salinity trend (Kakeh et al., 2018). The amount of sodium and potassium in the non-biocrusts compared with biocrusts has increased, which confirms the studies of Maqubela et al. (2009), which explain the reason for the increase of some soil elements due to the presence of biocrusts, as follows: copper, sodium, potassium, and zinc stick to the outer surface of the cell wall of the mosses. When wet and does dry, the elements are washed from the lichens and enter the soil, due to their positive load they are absorbed by clay colloids that have negative charges, resulting in an increase in their amount in such soils. Significant changes in the soil EC are observed between the biocrusts and bare soils (Table 2).

Increasing salinity and clay content prevents vegetation deployment and biocrusts (increasing clay content in non-biocrusts). Increasing clay accumulation at the soil surface decreases soil infiltration. It will only be able to moisturize the superficial layer, in this situation, an increase in the amount of evaporation from the surface layer of the soil leads to an increase in the accumulation of minerals from the elements of sodium, calcium and magnesium in this layer. So, the high amount of calcium and magnesium in the non-biocrusts and bare soils is justified.

Many studies have shown the effective role of biocrusts in the weathering of parent material, soil formation and particle size distribution (Aghamiri and Schwartzman, 2002; Souza-Egipsy et al., 2004). Soil organic carbon was higher in biocrusts surface soils than non-biocrusts, likely due to the ability of biocrusts to fix atmospheric C (Thomas et al., 2008; Zaady et al., 2000). This leads to enhanced biocrust biomass and thus SOC in the surface soil layer (0$5 \mathrm{~cm}$ ) (Chamizo et al., 2012a). Even a thin layer of photo synthetically layer on the soil can be important sources of organic carbon input (Zaady et al., 2000). Biocrusts also produce and secrete extracellular polysaccharides into surrounding soils, increasing the soil C pool (Mager and Thomas, 2011).

Biocrusts have an important role in the production of the SOC by carbon fixation (Beymer and Klopatek, 1991) and decomposition of organic matter (Danin and Ganor, 1991) in arid soils. Phillips and Belnap (1998) and Zhao et al. (2013) argued that carbon stabilization has been increased in the presence of lichen and moss. Base structures have more organic carbon compared to other structures, and there is an inverse relationship between SOC and soil $\mathrm{pH}$. An increase in carbon in the Playa region (non-biocrusts) is due to the dust that is deposited by the wind and the habitat of ants and termites 
(Kidron, 2016). Cyanobacteria can induce carbon dioxide to calcium carbonate (Wierzchos et al., 2012); because of the decrease in calcium carbonate content in non-biocrusts and bare soils, it can be concluded that cyanobacteria decrease at these levels. Soil texture shows the relative frequency of sand, clay and silt particles in soil samples.

Previous study has shown that soils with silty loamy texture are more likely to hold different populations of cyanobacteria, lichens and mosses compared to clay soils (Kleiner and Harper, 1997). Hydrological processes, aggregation and soil for- mation can be related to biological activities (Miralles et al., 2012). Sediment and desert dusts can aggregate with wind velocity, so in small catchments, the aggregation will be done in rock cracks (Hirmas et al., 2011). In a wider range, it improves topography and sediment accumulation patterns, the solid rocky surface of the desert pavement, with a smooth topography, capture less dust (Hirmes et al., 2011). As a result, a significant increase in the percentage of clay in the biocrusts compared with the bare soil can be attributed to dust capture in the biocrusts of the soil surface.
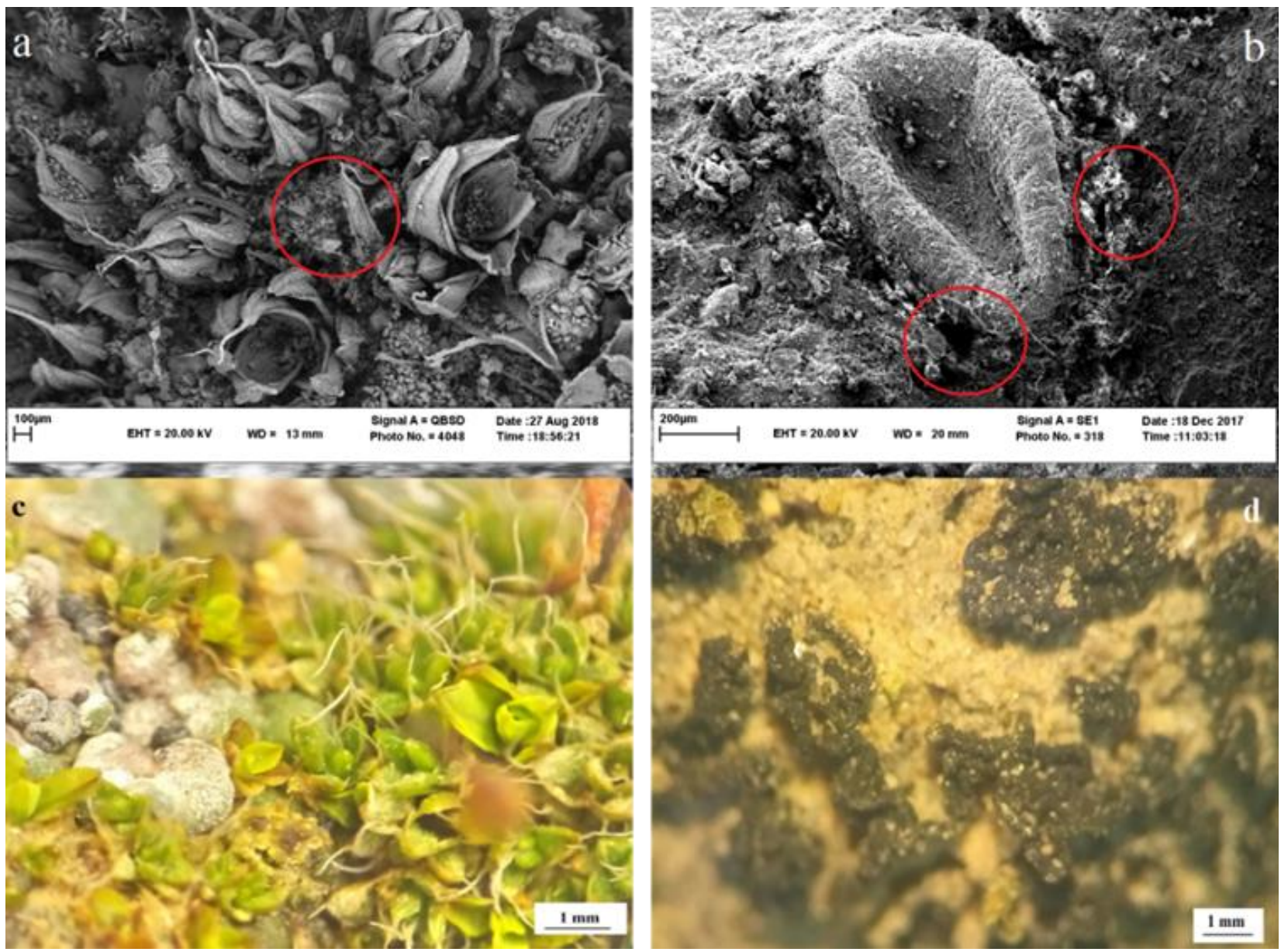

Figure 5 The red circle in image shows that fungal heifers are attached to the soil. a) SEM of mosses; b) SEM of lichens; c) Tortula atrovirens, d) Collema sp.

\subsection{The role of biocrusts in soil stability}

The biological activities of cyanobacteria, mosses and lichens have an important impact on soil erosion. The biocrust formed an enhanced contact structure composed of fine mineral particles. Early cyanobacterial crusts become stabilized when cyanobacteria polysaccharides that bind the soil particles, whereas late cyanobacterial crusts achieve stabilization by secreting filamentous and polysaccharides (Zhang et al., 2016). Mosses trap dust among 
their caulidia and fix by rhizoid (Figs. 4 and 5). The extensive connections between sand grains of the sheath material can be seen, and multiple sheets can often be seen attached to the same sand grain. The polysaccharide attached clay particles. This may be a mechanism by which cyanobacteria increase mineral availability to themselves and vascular plants. Positively charged macronutrients are bound to both negatively charged clay particles and the sheath materials; thus, they are held in the upper soil horizons in a form readily available to vascular plants, instead of being leached away (Belnap and Gardner, 1993).

Cyanobacteria and lichens fix dust particles to their polysaccharide sheaths, which become sticky when wet (Farpoor and Krouse, 2008). Trapped dust was thought to be important for creating a crust rich in clay and fine silt (Fig. 4). At the lichen stage, the crusts bind sand particles tightly with mycelium to form a stable layer. The moss profile shows that the moss rhizomes have kept the particles of soil building an extremely stable surface (Fig. 5).

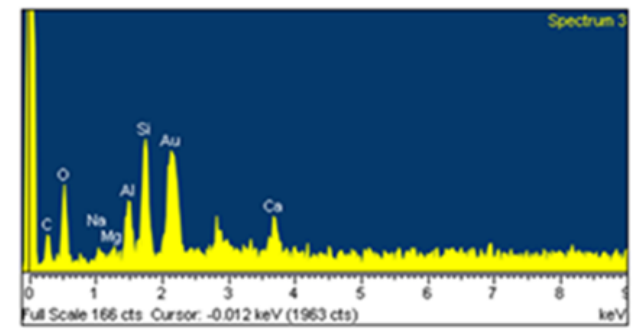

\begin{tabular}{c|c|c}
\hline Element & Weight\% & Atomic\% \\
\hline $\mathrm{CaCO} 3$ & 28.7 & 65.95 \\
\hline $\mathrm{SiO} 2$ & 2.16 & 2.13 \\
Wollastonite & 4.44 & 3.06 \\
\hline $\mathrm{Au}$ & 52.2 & 7.31 \\
\hline
\end{tabular}

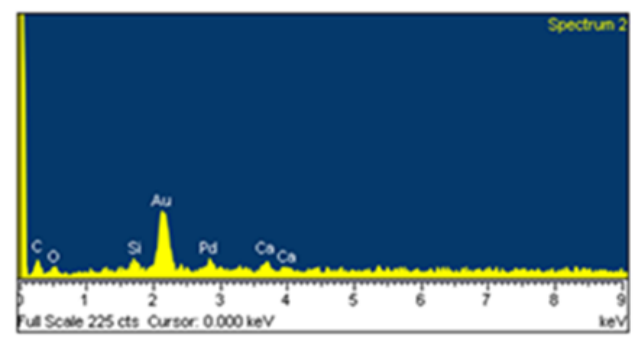

\begin{tabular}{c|c|c}
\hline Element & Weight\% & Atomic\% \\
\hline $\mathrm{CaCO} 3$ & 28.3 & 38.45 \\
\hline $\mathrm{Na}$ (Albite) & 1.3 & 0.92 \\
$\mathrm{MgO}$ & 1.15 & 0.77 \\
\hline $\mathrm{A} 12 \mathrm{O} 3$ & 5.76 & 3.48 \\
\hline $\mathrm{SiO} 2$ & 12.17 & 7.07 \\
Wollastonite & 5.01 & 2.04 \\
\hline
\end{tabular}

Figure 6 The EDS spectrum of the soil surface, along with the lichens and mosses biofilm and the percentage of its elements

Recovery or development of biocrusts makes changes on soil stability, resulting in increased biological activity. Consistent with our study, Danin and Ganor (1991) found calcite concentrations increased in biological surface soil. Hu et al. (2002) explained that changes in the numbers and species of algae were responsible for the mineralogical component variety in bio-crust at Shapoutou. Hyphae of lichen and rhizoid of mosses can physically break down quartz. Lamas et al. (1995) found that the influence and growth of hyphae occur both horizontally and vertically and may exceed $5 \mathrm{~mm}$, mainly via intergranular voids. Mineral surfaces are often affected by considerable amounts of organic covering (Krumbein and Dyer, 1985) that are produced by cyanobacteria, fungi and algae as well as higher organisms that inhabit external and internal (fissure/fracture) surfaces of mineral substrates (Fig. 4; polysaccharides and the eroding effect).
This research showed that biocrusts contribute to mineral erosion, and after analysing the physicochemical properties, we found that the main properties which showed significant differences with crust and bare soils were $\mathrm{SOC}_{1} \mathrm{CaCO}_{3}$ and amount of clay.

\section{Conclusion}

Cyanobacteria can grow on the soil surface hence promoting the formation of biocrusts in arid and semi-arid areas and protect the soil against erosion conditions. Experimental analyses indicate that key physicochemical properties of $\mathrm{OC}$ and $\mathrm{CaCO}_{3}$ differed between biocrusts and bare soil significantly in terms of different types of biocrusts. In general, in the TS, physicochemical property measurements were higher in bio-crusted surface soils when compared to the bare soil at the same depth. It is con- 
cluded that in the semiarid catchment in eastern Iran the presence of biocrusts generally increased the positive qualities of the soil. Our study reinforces the notion that biocrusts are important for maintaining and improving the soil conditions.

\section{Acknowledgements}

This work was funded by "Ferdowsi University of Mashhad" (Grant Number: 3-44201).

\section{Appendix}
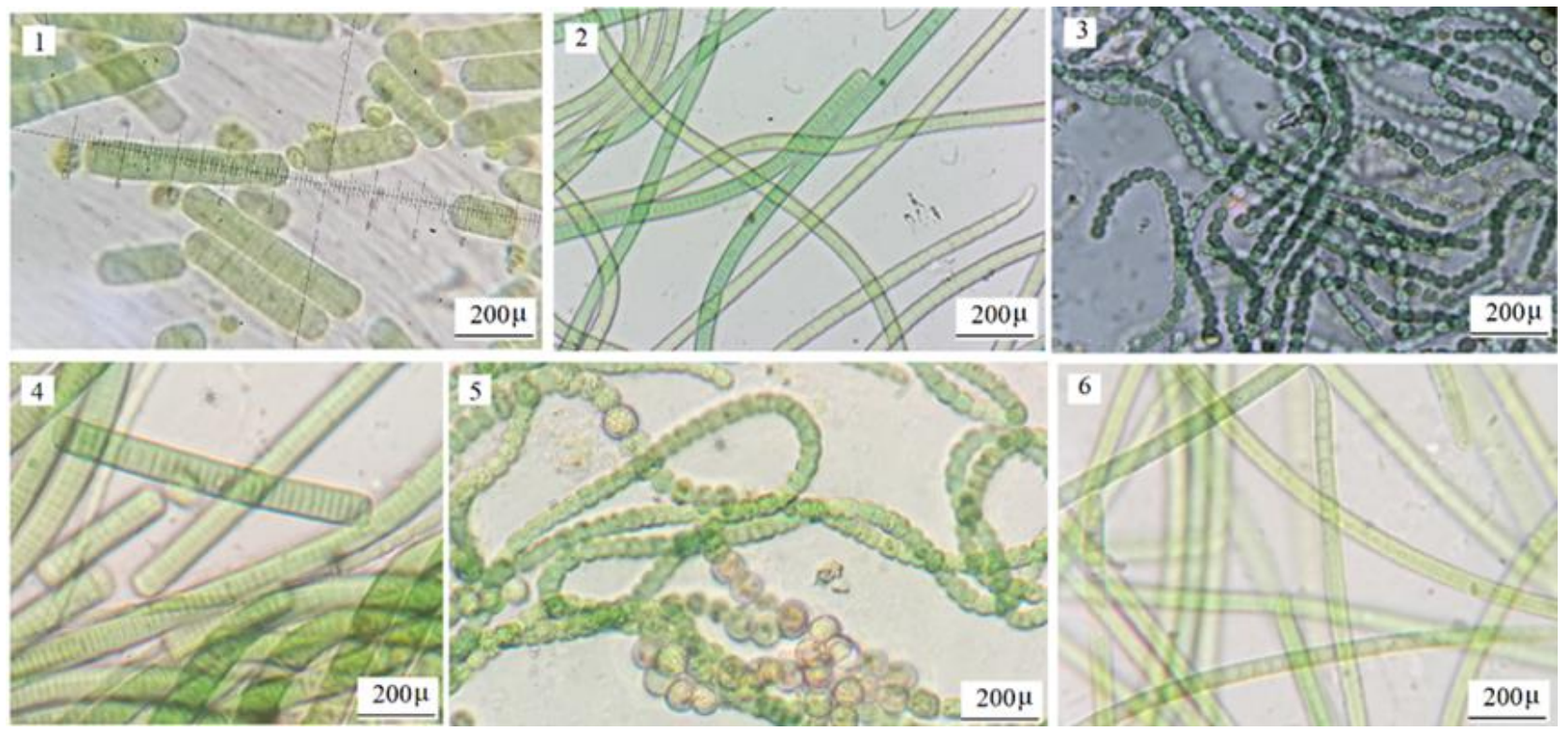

Figure 7 Cyanobacteria species identified in soil surface samples $(0-5 \mathrm{~cm})$ at the TS region: 1$)$ Leptolyngbya sp.; 2) Phormidium sp.; 3) Komvophoron sp.; 4) Oscillatoria sp.; 5) Nostoc sp.; 6) Phormidium sp. 
GHOLAMHOSSENIAN et al. / Revista de Geomorfologie 22 (2020)

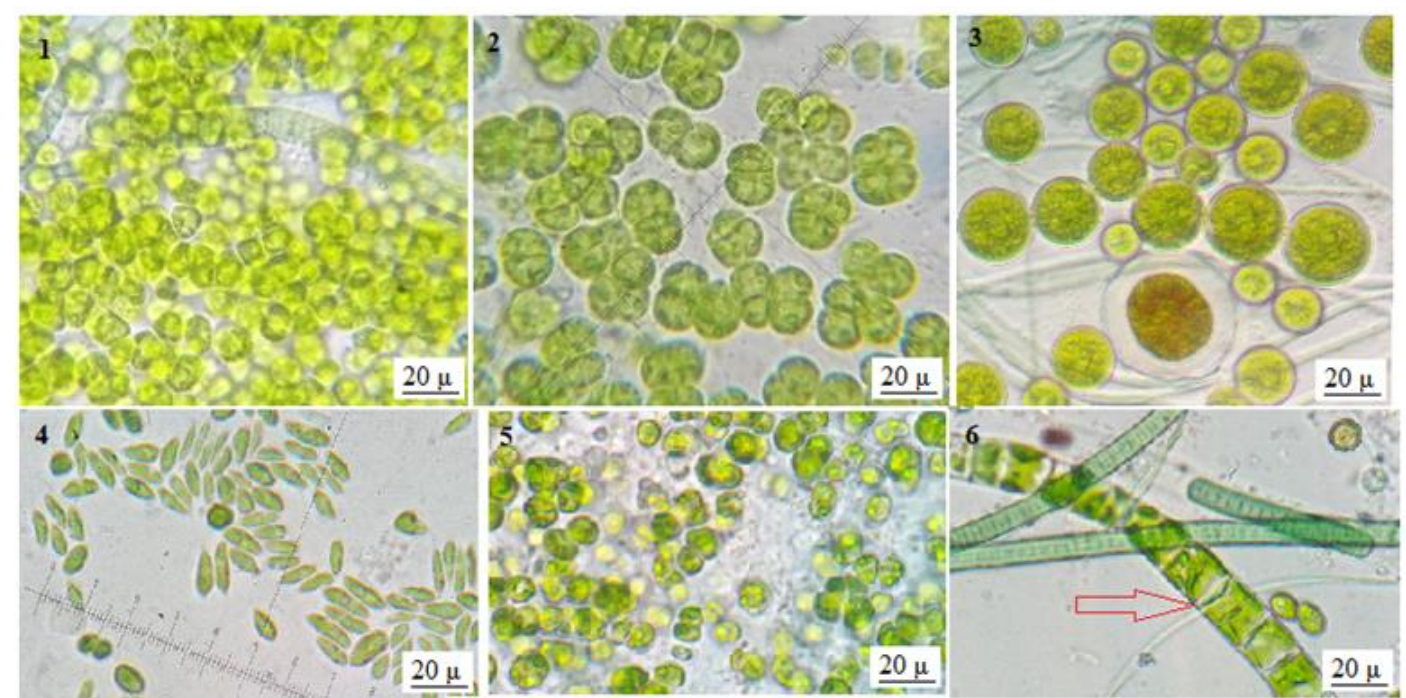

Figure 8 Green algae species identified in soil surface samples (0-5 cm) at the TS region: 1) Chlorella sp.; 2) Protococcus sp.; 3) Chlorococcum sp.; 4) Euglena sp.; 5) Planktosphaeria sp.; 6) Microspora sp.

Table 4 Biocrusts species found in samples of TS region and playa. Detailed picture of the different cyanobacteria and green algae species are shown in Figures 7 and 8 .

\begin{tabular}{|c|c|c|c|c|c|c|c|c|c|c|c|c|c|c|c|}
\hline & \multicolumn{3}{|c|}{ Cyanobacteria } & & \multicolumn{3}{|c|}{ Green Algea } & & \multicolumn{3}{|c|}{ Lichen } & & \multicolumn{3}{|c|}{ Bryophyte } \\
\hline & BSCS & NONBSCS & Playa & & BSCs & NONBBSCS & Playa & & BSCS & NON-BSCS & Paya & & $\mathrm{BSCS}$ & NON-BSCS & Playa \\
\hline Leprolyngbya boryana & $\checkmark$ & $\checkmark$ & . & Neochloris & $\checkmark$ & $\checkmark$ & $\cdot$ & Collema tenax & $\checkmark$ & . & . & Bytam argenteum & $\checkmark$ & . & - \\
\hline Microcoleus vaginatus & $\checkmark$ & $\checkmark$ & . & Chlorococcum & $\checkmark$ & $\checkmark$ & $\checkmark$ & Psora decipiens & $\checkmark$ & . & . & Tortula atrovirems & $\checkmark$ & . & . \\
\hline Nostoc commane & $\checkmark$ & $\checkmark$ & . & Chlorella & $\checkmark$ & $\checkmark$ & $\checkmark$ & Toninia candida & $\checkmark$ & . & . & Synbichia noralis & $\checkmark$ & . & \\
\hline Oscillatoria cueviceps & $\checkmark$ & $\checkmark$ & . & Planktosphlaeria & $\checkmark$ & $\checkmark$ & . & caloplaca microthallina & $\checkmark$ & . & . & Synbichia caninenis & $\checkmark$ & . & . \\
\hline Oscillatoria temuis & $\checkmark$ & $\checkmark$ & . & Rhizoclonitum & $\checkmark$ & $\checkmark$ & . & Circinaria mansourii & $\checkmark$ & . & . & & & & \\
\hline Oscillasoria chalybea & $\checkmark$ & . & . & Oedogonitum & $\checkmark$ & . & . & Leprogitom & $\checkmark$ & . & . & & & & \\
\hline Oscillatoria limosa & $\checkmark$ & . & . & Protocaccus & $\checkmark$ & $\checkmark$ & . & candelariella vitellina & $\checkmark$ & . & . & & & & \\
\hline Oocillatoria inigua & $\checkmark$ & . & . & Microspora & $\checkmark$ & & . & caloplaca microthallina & $\checkmark$ & . & . & & & & \\
\hline Phomaditum fonoston & $\checkmark$ & . & . & Englena & $\checkmark$ & . & . & caloplaca microthallina & $\checkmark$ & . & . & & & & \\
\hline Phomiditum amambiguumm & $\checkmark$ & . & . & & & & & Gyalolechia subbracteata & $\checkmark$ & . & . & & & & \\
\hline Phomiditom uncinatom & $\checkmark$ & $\checkmark$ & . & & & & & Rinodina bischoffi & $\checkmark$ & . & . & & & & \\
\hline Prendanabaena & $\checkmark$ & . & . & & & & & Endocarpon roviffliation & $\checkmark$ & . & - & & & & \\
\hline & & & & & & & & Endocarpon pusillum & $\checkmark$ & . & . & & & & \\
\hline & & & & & & & & Sarcogne & $\checkmark$ & . & . & & & & \\
\hline
\end{tabular}




\section{References}

Abed RM, Al-Sadi AM, Al-Shehi M, Al-Hinai S, Robinson MD. 2013. Diversity of free-living and lichenized fungal communities in biological soil crusts of the Sultanate of Oman and their role in improving soil properties. Soil Biology and Biochemistry, 57: 695-705.

Aghamiri RR, Schwartzman DW. 2002. Weathering rates of bedrock by lichens: a mini watershed study. Chemical Geology, 188(3-4): 249-259.

Belnap J. 2003(a). The world at your feet: desert biological soil crusts. Frontiers in Ecology and the Environment, 1(4): 181-189.

Belnap J. 2003 (b). Factors influencing nitrogen fixation and nitrogen release in biological soil crusts. In: Belnap J, Lange O. (eds.): Biological soil crusts: structure, function, and management, Springer-Verlag, Berlin, 241-261.

Belnap J. 2003 (c). Biological soil crusts in deserts: a short review of their role in soil fertility, stabilization, and water relations. Algological Studies, 109(1): 113-126.

Belnap J. 2006. The potential roles of biological soil crusts in dryland hydrologic cycles. Hydrological Processes. An International Journal, 20(15): 3159-3178.

Belnap J, Büdel B, Lange OL. 2001. Biological soil crusts: characteristics and distribution. In: Biological soil crusts: structure, function, and management, Springer, Berlin, Heidelberg, 3-30.

Belnap J, Büdel B, Lange OL. 2003. Biological soil crusts: characteristics and distribution. In: Belnap J, Lange OL (eds.): Biological soil crusts: structure, function and management, Springer-Verlag: Berlin; 3-30.

Belnap J, Gardner JS. 1993. Soil microstructure in soils of the Colorado Plateau: the role of the cyanobacterium Microcoleus vaginatus. The Great Basin Naturalist, 4047.

Belnap J, Harper KT. 1995. Influence of cryptobiotic soil crusts on elemental content of tissue of two desert seed plants. Arid Soil Res Rehabil, 9: 107-115.

Belnap J, Lange OL. 2013. Eds.: Biological soil crusts: structure, function, and management. Springer Science \& Business Media (Vol 150).

Beymer R, Klopatek J. 1991. Potential contribution of carbon by microphytic crusts in pinyon-juniper woodlands. Arid Land Research and Management, 5(3): 187-198.

Bilgrami KS, Saha LC. 2004. A Textbook of Algae. CBS Publishers and Distributors, 263p.

Bowker MA, Eldridge DJ, Val J, Soliveres S. 2013. Hydrology in a patterned landscape is co-engineered by soil-disturbing animals and biological crusts. Soil Biol. Biochem., 61(suppl. C): 14-22.
Büdel B. 2005. Microorganisms of biological crusts on soil surfaces. In: In: 425 Varma, A., Buscot, F. (Eds.), Microorganisms in Soils: Roles in Genesis and Functions, vol. 3, Springer, Berlin, pp. 307-323.

Buis CI, Geuken E, Visser DS, Kuipers F, Haagsma EB, Verkade HJ, Porte RJ. 2009. Altered bile composition after liver transplantation is associated with the development of nonanastomotic biliary structures. Journal of hepatology, 50(1): 69-79.

Chamizo S, Cantón Y, Miralles I, Domingo F. 2012a. Biological soil crust development affects physicochemical characteristics of soil surface in semiarid ecosystems. Soil Biol. Biochem., 49: 96-105.

Chamizo S, Cantón Y, LJzaro R, Solé-Benet A, Domingo F. $2012 b$. Crust composition and disturbance drive infiltration through biological soil crusts in semiarid ecosystems. Ecosystems, 15: 148-161.

Chen X, Duan Z. 2015. Impacts of soil crusts on soil physicochemical characteristics in different rainfall zones of the arid and semi-arid desert regions of northern China. Environmental Earth Sciences, 73(7): 3335-3347.

Coe BP, O'Roak BJ, Vives L, Girirajan S, Karakoc E, Krumm N, Levy R, Ko A, Lee C, Smith JD, Turner EH. 2012. Sporadic autism exomes reveal a highly interconnected protein network of de novo mutations. Nature, 485(7397): 246-250.

Cox AC, Hukins DWL, Sutton TM. 1989. Infection of catheterised patients: bacterial colonisation of encrusted Foley catheters shown by scanning electron microscopy. Urological research, 17(6): 349-352.

Danin A, Ganor E. 1991. Trapping of airborne dust by mosses in the Negev Desert, Israel. Earth Surface Processes and Landforms, 16(2): 153-162.

Delgado-Baquerizo $M$, Maestre FT, Bowker MA, Eldridge DJ, Cortina J, Lázaro R, Gallardo A, Berdugo M, Castillo-Monroy AP, Valencia E. 2016. Biological soil crusts as a model system in ecology. In: Biological Soil Crusts: An Organizing Principle in Drylands, Springer, Cham., 407-425.

Eldridge DJ, Greene RSB. 1994. Assessment of sediment yield by splash erosion on a semi-arid soil with varying cryptogram cover. Journal of Arid Environments, 26: 221-232.

Eldridge DJ, Zaady E, Shachak M. 2000. Infiltration through three contrasting biological soil crusts in patterned landscapes in the Negev, Israel. Catena, 40(3): 323-336.

Evans RD, Ehleringer JR. 1993. A break in the nitrogen cycle in aridlands. Evidence from dp $15 \mathrm{~N}$ of soils. Oecologia, 94: 314-317.

Evans RD, Johansen JR. 1999. Microbiotic crusts and ecosystem processes. Critical reviews in plant sciences, 18(2): 183-225. 
Fang HY, Cai QG, Chen H, Li QY. 2007. Mechanism of formation of physical soil crust in desert soils treated with straw checkerboards. Soil Tillage Res., 93: 222230.

Farpoor MH, Krouse HR. 2008. Stable isotope geochemistry of sulfur bearing minerals and clay mineralogy of some soils and sediments in Loot Desert, central Iran. Geoderma, 146(1): 283-290.

Gao S, Ye X, Chu Y, Dong M. 2010. Effects of biological soil crusts on profile distribution of soil water, organic carbon and total nitrogen in Mu Us Sandland, China. Journal of Plant Ecology, 3: 279-284.

Greene B, Darnall DW. 1990. Microbial oxygenic photoautotrophs (cyanobacteria and algae) for metal-ion binding. Microbial mineral recovery, 277-302.

Hirmas DR, Graham RC, Kendrick KJ. 2011. Soil-geomorphic significance of land surface characteristics in an arid mountain range, Mojave Desert, USA. Catena, 87(3): 408-420.

Hu C, Liu Y, Song L, Zhang D. 2002. Effect of desert soil algae on the stabilization of fine sands. Journal of Applied Phycology, 14: 281-292.

Issa OM, Défarge $C$, Le Bissonnais $Y$, Marin B, Duval $O$, Bruand A, d'Acqui LP, Nordenberg S, Annerman M. 2007. Effects of the inoculation of cyanobacteria on the microstructure and the structural stability of a tropical soil. Plant and soil, 290(1-2): 209-219.

Johnson SL, Budinoff CR, Belna J, Garcia-Pichel F. 2005. Relevance of ammonium oxidation within biological soil crust communities. Environmental Microbiology, 7(1): 1-12.

Kakeh J, Gorji M, Sohrabi M, Tavili A, Pourbabaee AA. 2018. Effects of biological soil crusts on some physicochemical characteristics of rangeland soils of Alagol, Turkmen Sahra, NE Iran. Soil and Tillage Research, 181: 152-159.

Karnieli A, Ben-Dor E, Patkin K, Banin A. 2002. Mapping of several soil properties using DAIS-7915 hyperspectral scanner data - a case study over clayey soils in Israel. International Journal of Remote Sensing, 23(6): 10431062.

Kaushik BD. 1987. Laboratory methods for blue green algae. Associated Publishing Company, New Delhi.

Kidron GJ. 2016. Linking surface and subsurface properties of biocrusted and non-biocrusted habitats of finegrained fluvial sediments (playas) from the Negev Desert. Journal of Hydrology and Hydromechanics, 64(2): 141-149.

Kleiner EF, Harper KT. 1977. Soil properties in relation to cryptogamic ground cover in Canyonlands National Park. J. Range. Manage., 30: 203-205.
Komárek J. 2005. The modern classification cyanoprokaryotes. Oceanological and Hydrobiological studies, XXXIV 3: 5-17.

Krumbein WE, Dyer BD. 1985. This Planet is Alive Weathering and Biology, A Multi-Facetted Problem . In: The chemistry of weathering, Springer, Dordrecht, 143-500.

Kumar D, Kaštánek P, Adhikary SP. 2016. Diversity of cyanobacteria in biological crusts on arid soils in the Eastern region of India and their molecular phylogeny. Current Science, (00113891), 110(10).

Lamas BP, Brea MR, Hermo BS. 1995. Colonization by lichens of granite churches in Galicia (northwest Spain). Science of the Total Environment, 167(1-3): 343-351.

Lane RW, Menon M, McQuaid JB, Adams DG, Thomas AD, Hoon SR, Dougill AJ. 2013. Laboratory analysis of the effects of elevated atmospheric carbon dioxide on respiration in biological soil crusts. J. Arid Environ., 98: 52-59.

Lange OL, Meyer A, Zellner H, Heber U. 1994. Photosynthesis and water relations of lichen soil crusts: field measurements in the coastal fog zone of the Namib Desert. Funct Ecol., 8: 253-264.

Liu Y, Li X, Xing Z, Zhao X, Pan Y. 2013. Responses of soil microbial biomass and community composition to biological soil crusts in the re-vegetated areas of the Tengger Desert. Applied Soil Ecology, 65: 52-59.

Luton PE, Wayne JM, Sharp RJ, Riley PW. 1999. The mcrA gene as an alternative to 16S rRNA in the phylogenetic analysis of methanogen populations in landfill. Microbiology, 148: 3521-3530.

Mager DM, Thomas AD. 2011. Extracellular polysaccharides from cyanobacterial soil crusts: a review of their role in dryland soil processes. Journal of Arid Environments, 75: 91-97.

Maier S, Muggia L, Kuske CR, Grube M. 2016. Bacteria and non-lichenized fungi within biological soil crusts biological soil crusts: an organizing principle in drylands, Springer, 81-100.

Maqubela M, Mnkeni P, Issa OM, Pardo M, D'Acqui L. 2009. Nostoc cyanobacterial inoculation in South African agricultural soils enhances soil structure, fertility, and maize growth. Plant and Soil, 315(1-2): 79-92.

McCune B, 1997. Key to the lichen genera of the Pacific Northwest. éditeur non identifié.

Meier LP, Kahr G. 1999. Determination of the cation exchange capacity (CEC) of clay minerals using the complexes of copper (II) ion with triethylenetetramine and tetraethylenepentamine. Clays and Clay Minerals, 47: 386-388.

Miller MB, Cooper TH, Rust RH. 2011. Diffraction of an eluvial fragipan from dense glacial till in northern Minnesota. Soil. Sci. Soc. Am. Journ., 57: 787-796. 
Mingorance MD, Barahona E, Fernández-Gálvez J. 2007. Guidelines for improving organic carbon recovery by the wet oxidation method. Chemosphere, 68: 409413.

Miralles I, Trasar-Cepeda C, Leirós MC, Gil-Sotres F. 2012. Labile carbon in biological soil crusts in the Tabernas desert, SE Spain. Soil Biology and Biochemistry, 58: 18.

Moniri MH, Sipman HJ. 2009. Lichens of two nature reserves in NE Iran. Willdenowia, 199-202.

Nelson DW, Sommers LE. 1982. Total carbon, organic carbon and organic matter. In: Page AL, Miller RH, Keeney DR (eds.): Methods of Soil Analysis Part 2, Chemical and Microbiological Properties, second edition, American Society of Agronomy, Soil Science Society of America: Madison, WI; 539-577.

Phillips SL, Belnap J. 1998. Shifting carbon dynamics due to the effects of Bromus tectorum invasion on biological soil crusts. Ecol Bull, 79, p. 205.

Prasse R, Bornkamm R. 2000. Effect of microbiotic soil surface crusts on emergence of vascular plants. Plant Ecology, 150: 65-75.

Qin S, Ferrara KW. 2007. The natural frequency of nonlinear oscillation of ultrasound contrast agents in microvessels. Ultrasound in medicine \& biology, 33(7): 1140-1148.

Rayment GE, Lyons DJ. 2011. Soil chemical methods: Australasia, 3. Collingwood: CSIRO.

Read CG, Popczun EJ, Roske CW, Lewis NS, Schaak RE. 2014. Highly active electrocatalysis of the hydrogen evolution reaction by cobalt phosphide nanoparticles. Angewandte Chemie, 126(21): 5531-5534.

Rogers SL, Burns RG. 1994. Changes in aggregate stability, nutrient status indigenous microbial populations, and seedling emergence, following inoculation of soil with Nostoc muscorum. Biology and Fertility of Soils, 18: 209-215.

Rozenstein O, Qin Z, Derimian Y, Karnieli A. 2014. Derivation of land surface temperature for Landsat-8 TIRS using a split window algorithm. Sensors, 14(4): 57685780 .
Souza-Egipsy V, Wierzchos J, Sancho C, Belmonte A, Ascaso C. 2004. Role of biological soil crust cover in bioweathering and protection of sandstones in a semiarid landscape (Torrollones de Gabarda, Huesca, Spain). Earth Surf. Process. Landforms, 29: 1651-1661.

Thomas AD, Hoon SR, Linton PE. 2008. Carbon dioxide fluxes from cyanobacteria crusted soils in the Kalahari. Appl. Soil Ecol., 39(3): 254-263.

Vijayan D, Ray JG. 2015. Ecology and diversity of Cyanobacteria in Kuttanadu paddy wetlands, Kerala, India. American Journal of Plant Sciences, 6(18), p. 2924.

West NE. 1990. Structure and Function of Soil Microphytic Crusts in Wildland Ecosystems of Arid and Semi-Arid Regions. Advances in Ecological Research, 20: 179223.

Wierzchos J. et al. 2012. Microorganisms in desert rocks: the edge of life on Earth. International Microbiology, 15(4): 173-183. doi: 573 10.2436/20.1501.01.170.

Xu Y, Rossi F, Colica G, Deng S, De Philippis R, Chen L. 2013. Use of cyanobacterial polysaccharides to promote shrub performances in desert soils: a potential approach for the restoration of desertified areas. Biology and fertility of soils, 49(2): 143-152.

Zaady E, Kuhn U, Wilske B, Sandoval-Soto L, Kesselmeier J. 2000. Patterns of $\mathrm{CO} 2$ exchange in biological soil crusts of successional age. Soil Biol. Biochem., 32: 959-966.

Zedda L, Gröngröft A, Schultz M, Petersen A, Mills A, Rambold G. 2011. Distribution patterns of soil lichens across the principal biomes of southern Africa. Journal of Arid Environments, 75(2): 215-220.

Zhang Y, Aradottir AL, Serpe M, Boeken B. 2016. Interactions of biological soil crusts with vascular plants. Biological Soil Crusts: An Organizing Principle in Drylands. Springer, 385-406.

Zhao L, Yin LJ, Zhai CZ, Chen M, Wang QY, Li LC, Xu ZS, Ma YZ. 2013. Two wheat glutathione peroxidase genes whose products are located in chloroplasts improve salt and $\mathrm{H} 2 \mathrm{O} 2$ tolerances in Arabidopsis. PloS One, 8(10): 73989. 